\title{
RELAÇÕES DE GÊNERO NA GUERRILHA: A CONFIGURAÇÃO DOS ESPAÇOS DE LUTA
}

Gender relations in the guerrilla: the configuration of the spaces of fight

Relaciones de género en el guerrillero: la configuración de los espacios de lucha

ELoÍsA Pereira BARroso ${ }^{*}$

https://doi.org/10.1590/S2178-149420210307

'Universidade de Brasília - Brasília (DF), Brasil.

*Doutora em Sociologia pela Universidade de Brasilia com doutorado sanduíche pela Frei Universität Berlin (eloisabarroso@uol.com.br)

(D) https://orcid.org/0000-0002-6850-0234

Artigo recebido em 25 de abril de 2021 e aprovado para publicação em 09 de julho de 2021. 


\title{
Resumo
}

0 artigo busca pensar as relações de gênero no contexto ditatorial vivido por mulheres guerrilheiras de modo a construir um diálogo entre passado, presente e futuro para se interpretarem as experiências vividas por elas com base em um horizonte dialógico e se compreenderem as disputas e tensões às quais elas estavam submetidas. A intenção é percorrer, por intermédio da história oral, a diversidade de espaços e tempos em que as relações se inscrevem tanto no campo do gênero como no campo da luta política, pois as experiências das mulheres guerrilheiras são sociais, portanto situadas no tempo/espaço.

PALAVRAS-CHAVE: Gênero; Mulheres; Ditadura Militar; História Oral; Identidade.

\begin{abstract}
The article seeks to reflect on gender relations in the dictatorial context as experienced by guerrilla women in order to build a dialogue between past, present and future to interpret the experiences lived by such women from a dialogical horizon and understand the disputes and tensions they were submitted to. The intention is to cover, through oral history, the diversity of spaces and times in which relations are inscribed both in the field of gender and in that of political struggle, since the experiences of guerrilla women are social, thus situated in the time/space.
\end{abstract}

KEYWORDS: Gender; Women; Military Dictatorship; Oral History; Identity.

\section{RESUMEN}

El artículo busca reflexionar sobre las relaciones de género en el contexto dictatorial vivido por las mujeres guerrilleras con el fin de construir un diálogo entre pasado, presente y futuro para interpretar las experiencias vividas por ellas desde un horizonte dialógico para comprender las disputas y tensiones que estaban sujetas. La intención es cubrir, a través de la historia oral, la diversidad de espacios y tiempos en los que se inscriben las relaciones tanto en el campo de género como en el campo de la lucha política, ya que las vivencias de las guerrilleras son vivencias sociales, las cuales se sitúan en el espacio de tiempo.

PALABRAS CLAVE: Género, Mujeres, Dictadura Militar, Historia Oral, Identidad. 
s escritos sobre a ditadura militar no Brasil têm-se intensificado a cada ano. Estudos sobre essa temática constituem-se de formas variadas. Seja nas análises das instituiç̧ões, seja na análise dos discursos das instituições do Estado ou dos movimentos sociais, ou, ainda, dos relatos daqueles que experienciaram o regime ditatorial, a produção de sentidos sobre o Golpe de 1964, no que tange à política, à economia e à cultura, está atravessada por representações que perpassam pela constituição de memórias em disputa sobre o período. Baseada nessas disputas de memórias, a leitura da ditadura militar constitui-se em representações calcadas em imaginários que se efetivam em memórias legitimadas, ou não, nas narrativas postas.

Para Pollak (1989), as memórias em disputa redefinem os objetos de pesquisa, que passam a expor os conflitos presentes na competição entre memórias concorrentes. Dessa maneira, cada vez mais, a memória tem possibilitado revisões historiográficas de forma a iluminar as tensões da luta política; as estratégias dos processos de silenciamento sobre as cisões sociais em determinados períodos da história; as relações de poder presentes nas versões sobre os fatos sociais; enfim, essas disputas permitem a possibilidade de outra interpretação do fato social (Pollak, 1989: 5).

A militância política de mulheres na ditadura militar brasileira é um campo de estudos que vem ganhando espaço nessas memórias em disputa, o que subverte as representações comumente associadas ao papel da mulher nesse espaço de tempo. As pesquisas têm mostrado que muitas assumiram diferentes protagonismos no processo político de constituição das resistências. Os estudos mostram que, no campo das relações de gênero, muitas mulheres romperam os códigos de conduta esperados ao se apropriarem do espaço da política como guerrilheiras. Pollak (1989) vê a história oral contemporânea como um movimento capaz de contestar o caráter destruidor, uniformizador e opressor da memória coletiva nacional. Ela faz emergir as memórias subterrâneas, as quais questionam o caráter de verdade da memória selecionada como oficial. Dessa maneira, analisar a participação das mulheres no processo de resistência à ditadura, com base na história oral, é oferecer à história informações que permitem, no contexto autoritário de um regime que surrupiou a democracia, o entendimento de como, em ambiente tão controverso, as mulheres construíram identidades sociais associadas à participação política como protagonistas no processo de luta armada.

A história oral, na contemporaneidade, tem-se colocado no campo científico como uma possibilidade importante na reverberação das memórias coletivas e na construção de regimes de verdades. Ao voltar-se para o passado, recompõe e ressignifica os cacos do pre- 
térito que insistem em permanecer no presente. Muitas vezes relegadas nos registros oficiais da história, as mulheres guerrilheiras praticaram, guardaram e compartilharam umas com as outras as sutilezas e as práticas às quais recorreram durante o processo de resistência à ditadura militar no Brasil. Como salienta Natalie Zemon Davis, "a maior parte do que conhecemos nos é transmitida por homens, e em trabalhos literários, textos normativos, tratados morais e expressões artísticas, ou as mulheres estão completamente ausentes, ou são encontradas dentro do discurso de homens sobre mulheres" (Davis, 1976 apud Salvatici, 2005: 30).

Disseminadas a partir da década de 1960, a história oral e a história de mulheres buscam encontrar as histórias invisibilizadas. Enquanto os historiadores orais têm procurado reverberar as vozes ocultadas pela história, as mulheres buscam ressignificar o papel desempenhado por elas nas diferentes temporalidades. 0 interesse pelas narrativas das mulheres tem colocado para a ciência novas possibilidades para a releitura de significados reificados pelas narrativas masculinas. Assim, a vida diária, as atividades domésticas e as esferas da vida privada e pública da vivência de mulheres validam as experiências femininas na historiografia, que cada vez mais se constitui em um campo do saber fundamental para a compreensão das democracias contemporâneas. Ao incluir as suas vozes como vozes pertencentes a sujeitas sociais, as mulheres possibilitam ao mundo social a formulação de outras memórias que não somente aquelas costumeiramente presentes nos manuais de história (Salvatici, 2005: 29).

A história oral pode orientar o processo de rememorar e relembrar os sujeitos. As narrativas expressas nas falas de quem testemunhou e experienciou uma determinada situação demonstram que a memória se efetiva nos atos de fala como processo de construção e reconstrução de lembranças nas condições postas pelo tempo presente. Dessa maneira, o campo da história oral consubstancia-se como o lugar do entrelaçamento entre a história, a memória e a identidade. Nele, o respeito e a ética são imprescindíveis, visto que "a relação sujeito-outro necessita ser contemplada em um processo que envolve individualidades e onde as diferenças devem ser respeitadas" (Ferreira e Grossi, 2004: 50).

Segundo Portelli (1997), a história oral é "uma ciência e arte do indivíduo", na qual o campo, mesmo que intimamente relacionado a padrões culturais, a estruturas sociais ou a processos históricos, realiza-se na conversa com pessoas singulares portadoras de individualidades; para o autor, "apesar de o trabalho de campo ser importante para todas as ciências sociais, a história oral é, por definição, impossível sem ele" (Portelli, 1997: 15). Posto isso, a ética e o respeito são imprescindíveis nesses contatos humanos diretos entre quem escuta e quem narra. Procurar-se-á no trabalho com história oral o respeito pelo valor e pela importância de cada indivíduo, as lições sobre ética levam à reflexão sobre a experiência com o trabalho de campo como um exercício que busca tanto os santos e os heróis como os tiranos e 
as vítimas, os transgressores, os artistas, entre tantos outros sujeitos; no caso deste artigo, as mulheres que protagonizaram a guerrilha urbana entre os anos de 1968 e 1972.

0 início da década de 1960 representa um período de grande efervescência para a sociedade brasileira; o movimento estudantil e as esquerdas mobilizavam-se por reformas sociais. A luta por mais igualdade e distribuição de renda deu a tônica no território nacional para as campanhas em prol de um projeto de democracia radical a ser consolidado com as reformas de base propostas pelo governo de João Goulart. Entretanto, em 1964, o vigor dos anos anteriores foi substituído por um silêncio imposto pelo golpe militar. 0 burburinho das ruas, com os manifestantes empunhando faixas e gritando palavras de ordem, deu lugar às rondas dos militares em seus carros de patrulhas ou montados em cavalos para garantir a ordem. Impossibilitados de se expressarem, com a União Nacional dos Estudantes (UNE) colocada na ilegalidade e a maior parte dos partidos políticos extinta, o movimento estudantil e as esquerdas mudaram suas pautas de reivindicações. A necessidade impunha a resistência ao projeto ditatorial e à repressão policial. Até o ano de 1968 ainda foi possível organizar atos, fazer manifestações; mas eis que, em 13 de dezembro de 1968, o governo decretou 0 Ato Institucional número 5 (Al-5). Embora outros atos o tenham antecedido, nenhum obteve 0 alcance do Al-5, que institucionalizou o poder absoluto do Estado na supressão dos direitos e das liberdades individuais. 0 Al-5 legalizou a tortura e abriu as portas para prisões e assassinatos dos contrários ao regime.

Com o Al-5, a resistência saiu do campo das ideias e adotou o conflito; não havia mais debate, não havia mais passeatas. 0 confronto substituiu as manifestações pacíficas, a luta armada tomou as ruas da cidade e os espaços do campo. A resistência armada foi a forma de contestação pela qual um braço da esquerda optou. Em contrapartida, a tortura e o assassinato foram as medidas adotadas pelo governo para debelar os contrários ao regime. A Lei de Segurança Nacional sustentava ideologicamente as ações do Estado ditatorial, o que impedia o ideário de libertação dos movimentos artísticos, sociais e estudantis.

Após o Al-5, o Estado refinou seus órgão de inteligência por meio do Sistema Nacional de Informação (SNI) e do Destacamento de Operações de Informação/Centro de Operações de Defesa Interna (DOI/CODI) e criou redes de espionagem que conseguiram adentrar os núcleos dos movimentos de resistência armada. 0 modus operandi de vigiar, perseguir, torturar e, muitas vezes, assassinar foi aperfeiçoado.

Nesse Estado opressor, policialesco, muitos jovens guerrilheiros foram parar na clandestinidade. Para defenderem o projeto de reconstrução da democracia e, por consequência, a transformação de valores e costumes, precisaram construir novas identidades; era necessário encontrar novas formas de existir. Grande parte dessa juventude situava-se na faixa etária 
entre 14 e 30 anos. Segundo Abreu (1997), essa juventude revolucionária, ao compartilhar aquela conjuntura histórica de opressão, colocou-se enquanto projeto derrubar o regime militar com a luta armada. Mas Abreu assinala que, somando-se à restituição da democracia, outros projetos aliaram-se a essa pauta, tais como a revolução dos costumes.

Se considerarmos essa perspectiva proposta por Abreu, talvez seja possível afirmar que, quando verificamos a participação das mulheres na luta armada nos anos de 1960 e início de 1970, é possível afirmarmos que a militância política se define como o início de um processo de ruptura com o papel designado à mulher. Ao pegar em armas e lutar por uma causa pública, as guerrilheiras questionaram a tradicional hierarquia de gênero.

Naquele momento, quando se observa a participação da mulher na política em uma situação de conflito extremado, percebe-se que ao contestar as relações de poder a sua presença na luta armada implicou bem mais do que insurgir-se contra a ordem política vigente; tornar-se guerrilheira foi um ato de profunda transgressão.

Desde a redemocratização, embora tenhamos uma quantidade significativa de registros, grande parcela dos sujeitos que vivenciaram a ditadura como opositores ao regime não contaram suas histórias por motivos diversos, e a mulher, embora com as Comissões da Verdade nacional e regionais, ainda tem poucos registros de sua voz. Portanto, o testemunho daquelas que ousaram resistir ao regime, por meio do conteúdo de suas narrativas, pode compor parte do repertório sociocultural daquele período no Brasil, o que contribui para revelar aspectos da história de um regime que deflagrou o arbítrio e suprimiu as liberdades.

Cabe salientar que só recentemente a historiografia tem analisado os anos da ditadura militar com base nos depoimentos daqueles que experienciaram os acontecimentos dos mais de 20 anos do regime ditatorial. Os testemunhos dos perseguidos pelo regime contam histórias e narram fatos antes silenciados. As mulheres, embora poucas tenham registrado sua participação, quando falam elaboram narrativas permeadas por um processo de luta calcado em estratégias que revelam uma história ainda pouco narrada. Assim, ao lidarmos com as identidades e as relações de gênero nesse período com base no depoimento de guerrilheiras, propomo-nos a refletir sobre as motivações das mulheres para a participação política e os reflexos dessa participação nas suas vidas e para as mulheres em geral. A proposta é considerar o conjunto de fatores que levaram as mulheres a saírem do espaço privado a elas destinados e se apropriarem do espaço público fazendo uso da participação política, para tentar compreender os reflexos dessa participação social das mulheres entrevistadas. Portanto, busca-se aqui uma dimensão traduzida pelo reconhecimento das convergências e das diferenças, por meio do afloramento de lembranças e esquecimentos na construção das representações sobre o passado por meio da história oral. 
A memória e a história, postas na produção de fontes orais, colocam-se no campo dos processos cognitivos em que as identidades dos sujeitos são analisadas como parte constitutiva da narrativa histórica. É importante salientar ainda que os depoimentos fazem emergir no presente disputas de memória, na medida em que evidenciam as memórias subterrâneas que, ao chegarem à superfície, disputam a proposição de outras interpretações, o que acaba por questionar o estatuto de regimes de verdades estabelecidos pelos discursos. No que se refere à ditadura militar, para além da análise das fontes, coloca-se em questão o debate sobre a apropriação da memória de uma história silenciada no que tange à ação tanto do Estado como dos movimentos de esquerda pela história oral. A história oral comumente nos impõe a problemática historiográfica; dado que focamos estudos do tempo presente, impomo-nos enquanto missão a reflexão sobre um passado ainda próximo. Nesse campo, a memória adquire uma função primordial ao colocar em evidência as experiências de quem esteve presente nesses eventos. É no ato de lembrar que os sujeitos falam, falas estas que misturam tempo presente e tempo passado, representações individuais e coletivas de compreensão e explicação do contexto social.

Quando se pensa a análise das ações de mulheres na guerrilha, observa-se que apenas no final do século XX se iniciou uma reflexão acadêmica mais acurada sobre o papel do gênero feminino na resistência à ditadura. Esses debates sobre o passado de mulheres que se apropriaram do espaço público trouxeram alguns desafios aos historiadores que abordam o tempo presente. Pesquisas a respeito da temática desenvolvidas pelas professoras Marta Rovai, Ana Maria Colling, Albertina Oliveira Costa, Olívia Rangel Joffily, Margareth Rago, Maria Cláudia Badan Ribeiro, entre tantas outras, iluminam as experiências e seus significados vividos e partilhados por mulheres guerrilheiras que, em seus relatos, expõem traumas individuais, coletivos e históricos. Os trabalhos historiográficos do tempo presente têm cada vez mais desvelado memórias na contemporaneidade que qualificam a importância da história oral de mulheres. Como nos alerta Paul Ricoeur, a "história do tempo presente [...] está numa outra fronteira, aquela onde esbarram uma na outra a palavra das testemunhas ainda vivas e a escrita em que já se recolhem os rastros documentários dos acontecimentos considerados" (Ricoeur, 2007: 456).

A memória está para além de um dever; ela é "uma necessidade jurídica, política e moral" (Sarlo, 2007: 47). As memórias sobre a ditadura militar brasileira e, especificamente, sobre a ação das guerrilheiras nesse período, configuram-se como memórias em disputa no que tange aos debates sobre identidades. As memórias que apontam a participação das mulheres sem uma reflexão crítica hoje concorrem com aquelas que expõem as rotinas, as ideologias e as subjetividades das guerrilheiras. Segundo Susana Funck, um dos maiores de- 
safios da produção de conhecimento sobre gênero é "desmistificar a prática feminista como uma unanimidade monolítica e fazer valer as várias facetas da categoria gênero, perpassadas como são por vetores de raça, classe, nacionalidade, sexualidade, faixa etária e tantas outras diferenças" (Funck, 2014: 23).

Ao refletir sobre a prática feminista, Funck (2014) nos permite uma leitura atenta para procedermos à análise, via representações sociais, sobre o comportamento das mulheres guerrilheiras no espaço da política, na qual se entrecruzam diversas categorias para a constituição da trama histórica, urdidas pelas relações de gênero.

Assim, as memórias de Joana e Fernanda são exemplos para pensarmos as articulações entre narrativas, identidades e usos políticos da memória na construção de um relato. As falas demonstram, também, o lugar da história oral na narrativa sobre o passado. Ao nos depararmos com as falas das guerrilheiras, somos colocados diante de diferentes fluxos narrativos que dialogam e se complementam de maneira a conferir sentido e densidade à luta feminina nos grupos de luta armada. Joana e Fernanda têm em comum o fato de serem provenientes de famílias de classe média e de terem militado em organizações de esquerda de resistência à Ditadura. Joana foi estudante do Colégio Liceu de Goiânia, onde, por meio do Grêmio Estudantil, inseriu-se no movimento armado. Filha de um coletor de impostos, exerceu grande parte de sua militância na organização Vanguarda Armada Revolucionária Palmares (VAR-Palmares). Fernanda, filha de pai comunista e mãe proveniente da classe média goiana, que sonhava ver a filha se tornar pianista, estudava assim como Joana no Liceu de Goiânia, onde, também por meio de atuações no Grêmio Estudantil, conheceu o movimento de guerriIha e tornou-se membro da VAR-Palmares.

Essas duas mulheres, apesar do sofrimento que suas recordações provocam, procuram reconstruir uma história ainda pouco visibilizada. Segundo as entrevistadas, falar sobre esse tempo é uma questão ética e política. Elas já não podem mais silenciar aspectos relevantes para a consolidação da democracia, pois têm o dever moral de construírem um país no qual acontecimentos tão brutais possam retornar. A entrevista com Joana ocorreu no dia 4 de fevereiro de 2016 e a com Fernanda no dia 6 de fevereiro de 2016, em suas residências. A opção por não usar os nomes verdadeiros deve-se ao fato de as narradoras preferirem manter seu anonimato. As entrevistas foram seguidas de um roteiro semiestruturado; porém, procurou-se fazer um exercício de escuta sensível das questões postas pelas entrevistadas. Nas entrevistas, as mulheres falaram livremente de suas trajetórias de vida desde a infância, passando pela adolescência e até os dias atuais, enfatizando sua participação política e sua inserção nos grupos sociais dos quais participaram durante a ditadura militar. A análise dos dados colhidos perpassou por categorias de análise tais como identidade, representações, experiência e gê- 
nero na construção da trajetória de militância dessas mulheres no período. Nessa perspectiva, o trabalho com a história oral neste artigo ganha um papel social, pois, ao tornar públicas as experiências das mulheres que se dispuseram a contar as suas histórias, as quais tiveram a oportunidade da leitura prévia das análises aqui postas, possibilita para os possíveis leitores reconhecê-las como parte de um passado e de um presente coletivos.

As análises das memórias desse tempo, baseadas no relato das experiências dessas mulheres que vivenciaram esse período, permitem uma leitura da origem da experiência de gênero como uma experiência radical, no sentido de ser fundada em uma ideia e em uma posição definidas em um espaço de conflito. Segundo Ridenti, a participação dessas mulheres na luta armada contra o regime militar instituiu o rompimento com "o estereótipo da mulher restrita ao espaço privado e doméstico, enquanto mãe, esposa, irmã e dona de casa, que vive em função do mundo masculino" (Ridenti, 1990: 114). Esse processo de ruptura foi o responsável por outras maneiras de participação social, como nos mostra Joana.

Em 1967 eu entrei para o [Setor de Ações Violentas] SAV, porque eles precisavam de mulher para vigiar, e não tinha mulher, então eu entrei, eu não queria o setor rural.. No SAV eu treinava para atirar. la pros aparelhos, a organização alugava apartamentos, que eram os aparelhos, ia para as reuniões, tudo era muito secreto, a gente ia de Fusca, às vezes para a fazenda, mas sempre com uma venda nos olhos, é, os olhos eram tampados para a gente não reconhecer o caminho, porque se fosse preso a gente não poderia dizer, nas reuniões a gente fazia panfletos e rodava em mimeógrafos porque quando a gente explodia bomba punha os panfletos que explicavam tudo, tudo que a gente acreditava. Ah, tinha muito aparelho na Praça Universitária, era nos aparelhos que ficavam os clandestinos. A organização alugava casas, apartamentos em lugares bem discretos, na periferia e no Setor Universitário [...] (Joana, Informação Verbal). ${ }^{1}$

As ações das guerrilheiras podem ser lidas como formas de se contestar o processo de reificação que naturaliza as relações de poder estabelecidas na sociedade, na qual as relações de gênero se inserem na estrutura social. Embora muitas mulheres não tivessem papel de destaque nas organizações e fossem minoria, sua participação configura-se como um processo de ruptura na medida em que, conforme Ridenti (1990), marca um processo de emancipação, pois elas contestaram a ordem estabelecida em todos os níveis ao questionarem a hierarquia de gênero posta, naquele momento, nos diversos âmbitos da sociedade. A militância política foi um importante instrumento para a emancipação feminina, embora as pautas feministas não estivessem presentes no seio das esquerdas armadas.

0 vínculo entre memória e identidade com base na ênfase em uma história contada por sujeitos do cotidiano valoriza os relatos orais de lembranças, o que nos permite pensar em identidades sociais nas suas múltiplas constituições. Nas falas de Joana e de Fernanda, 
é possível compreendermos as identidades sustentadas pelas mulheres que adentraram a luta armada.

Ih! Fazia tudo. Dirigia, levava armas, tinha que fazer tudo mesmo por que? Era mais fácil pra mulher fazer várias coisas, o homem, ele... tinha mais homem, mulher tinham poucas, era pouca porque a mãe não deixava, porque na época, ainda mais sair de casa [...] (Joana, Informação Verbal).

Olha, eu tava pensando sobre isso, a gente tinha distinção... eu acho que tem, porque se você fala em união das mulheres porque separa as mulheres dos homens é porque as mulheres ainda não tão ocupando um espaço igualmente, eu acho, assim eu entendo dessa forma, né? O Clemente que foi um cara que eu fiquei bem próximo, que era do comando nacional, nós ficamos muito próximos, é... que o Mário não me ouça, mas o casamento era aberto e eu namorei o Clemente, entendeu?! E ele falava assim, eu lembro dele falar assim de uma companheira do Rio que era muito, que era uma pessoa muito forte que ela competia de igual pra igual com os homens, era a mulher que lia adoidado, que lia o capital, e as leituras que na época a gente fazia que era importante pro que a gente queria né, e eu me lembro que eu fiquei assim "poxa, essa mulher é legal, quero ser igual a ela!" (risos) [...] Olha, pelo que eu me lembre só os homens tinham cargos de chefia, não vejo nenhuma mulher. Você falou uma coisa importante, tarefas, a gente procurava assim... porque a mulher vai pro canto, porque homem vai pra cá, e aí a gente tinha essa noção de que precisava ter tarefas, que as tarefas fossem divididas igualmente, mas você não tem cabeças, é... liderando, que sejam cabeças femininas liderando. $E_{\text {, }}$ parecia isso, ele falava nossa, fulana é muito incrível, muito formada... eu comecei a admirar, num sei quem é essa mulher (risos) até hoje eu não sei quem é, mas ele falava pra mim, então era uma figura que tinha essa preocupação e até (Fernanda, Informação Verbal). ${ }^{2}$

Segundo Sarti (2004), a militância política nessa época, embora tenha contribuído para a emancipação feminina, não formulava uma proposta feminista; ao contrário, para se encaixarem na luta armada, muitas militantes tomaram para si comportamentos considerados próprios do universo masculino. Além de pegarem em armas e participarem de treinamentos considerados exaustivos para uma mulher, elas adotaram a liberdade sexual como um direito, atitudes que somadas a tantas outras produziram nelas uma aparente sensação de igualdade. Porém, ao analisar alguns depoimentos, a autora mostra que "a igualdade entre homens e mulheres era apenas retórica, fazendo a questão de gênero eclodir em suas contradições com o projeto de emancipação militante" (Sarti, 2004: 37). Isso pode ser observado quando Fernanda, em seu relato, salienta a ausência de cargos de liderança feminina nas organizações. Ela afirma ainda que vivenciar o casamento aberto não era uma experiência de igualdade, na medida em que, mesmo sendo acordada essa relação entre o marido e a esposa, até hoje 
o seu companheiro não pode saber de sua relação com o "Clemente". Há ainda a referência a uma mulher que era admirada pelo fato de ter adotado um comportamento considerado pertinente, naquele momento, ao universo masculino.

Embora os movimentos de mulheres não sejam recentes no Brasil, é preciso salientar que antes da década de 1960 as atuações femininas se concentravam em episódios específicos; não havia uma pauta mais profunda que reivindicasse os direitos da mulher na sociedade. A atuação das mulheres estava subordinada ao peso das tradições masculinas, pois muitas estavam sob a chancela dos maridos ou do Partido Comunista Brasileiro (PCB), instituições que consideravam a mulher um sexo frágil. Verifica-se a ausência de discursos específicos voltados para a definição da identidade política de mulheres que participavam dos movimentos de lutas por uma sociedade mais igualitária. Normalmente, essa participação foi calcada pelo esvaziamento político de suas ações, pois se considerava que suas propostas estavam reduzidas ao universo feminino; um exemplo disso foi a campanha pela paz mundial.

É nos setores radicalizados da esquerda, no regime ditatorial do fim dos anos 1960 e início dos anos 1970, que encontramos novas formas de atuação das mulheres. Elas apropriaram-se da esfera política e subverteram o conservadorismo social pautado em uma ortodoxia heteronormativa. A luta na guerrilha possibilitou a muitas tirarem lições para a elaboração e a difusão do pensamento feminista no Brasil. Cabe salientar que a emergência do feminismo aqui coincide com a vigência da ditadura militar. A atuação das mulheres, no interior dos grupos, misturou tanto a resistência ao regime como a busca de uma sociedade mais igualitária, colocando em questão as práticas políticas calcadas em um mundo masculino e a divisão entre vida privada e vida política.

Quando essas mulheres foram à luta e reivindicaram uma posição de igualdade nos movimentos políticos com os homens, elas defenderam com vigor suas convicções. Mesmo sendo apenas retórica, como afirma Sarti (2004), elas romperam com concepções que ainda as tomavam como indivíduos sujeitos à influência dos companheiros militantes. Isso demonstra que narrar a história das mulheres no Brasil é falar de lutas marcadas por pequenos avanços e muitas dificuldades, haja vista que a chegada da mulher à esfera pública como sujeito político não se realizou sem custos.

Compreender a multiplicidade das experiências das mulheres nas suas interações sociais é levar em consideração o dinamismo dos contextos sociais no tempo e no espaço de um período ditatorial permeado por uma cultura patriarcal. Isso porque as transformações pelas quais os sujeitos passam estão sujeitas a estruturas diferenciadas, as quais exercem influências na articulação de projetos de cunho pessoal e social. Assim, quando falamos de experiências de mulheres na guerrilha, é necessário estabelecermos 
uma discussão sobre identidade. Embora a guerrilha comporte uma pluralidade de manifestações, ressaltar a particularidade da articulação da experiência feminina nas ações de resistência fazendo-se uma leitura do momento histórico e político no qual se desenvolveu essa luta é também uma forma de pensar o legado dessas experiências que marcaram e diferenciaram as mulheres. A guerrilha modificou substancialmente formas de pensar e viver, além de impactar, sobremaneira, tanto o plano das instituições sociais e políticas como os costumes e hábitos cotidianos. As militantes políticas ampliaram definitivamente 0 espaço de atuação pública da mulher. Isso, talvez, porque, como afirma Stuart Hall, a abordagem discursiva das representações:

Recai invariavelmente sobre a especificidade histórica de forma particular ou de um "regime" de representação, e não sobre linguagem enquanto tema mais geral. Isto é, seu foco incide sobre linguagens ou significados e de que maneira eles são utilizados em um dado período ou local, apontando para uma grande especificidade histórica — a maneira como práticas representacionais operam em situações históricas concretas (Hall, 2016: 27).

Tomar a história da identidade das mulheres guerrilheiras como objeto de investigação implica necessariamente analisar o posicionamento dessas mulheres, em parte, pelo menos, como se produziu o efeito dos discursos que colocaram as guerrilheiras em uma condição política fincada em normas sexistas e calcadas em hierarquias de gêneros. Dessa maneira, trazer suas experiências vividas na luta armada é historicizar a "experiência" do gênero. Para Joan Scott (1998):

Precisamos nos referir aos processos históricos que, através do discurso, posicionam sujeitos e apresentam suas experiências. Não são indivíduos que têm experiência, mas sim os sujeitos que são constituídos pela experiência. Experiência nessa definição torna-se, então, não a origem da nossa explanação, não a evidência legitimadora (porque vista ou sentida) que fundamenta o que é conhecido, mas sim o que procuramos explicar, sobre o que o conhecimento é apresentado. Pensar sobre a experiência desse modo é historicizá-la, bem como historicizar as identidades que ela produz. [...] É uma historicização que implica exame crítico de todas as categorias explicativas tomadas normalmente como óbvias, incluindo a categoria da experiência (Scott, 1998: 304).

Portanto, tratar a emergência de uma nova identidade como um evento discursivo do qual o narrador participa é pensar os sujeitos na sua capacidade de agenciamento e produção de significados nas representações de si. Significa, ainda, insistir na qualidade produtiva do discurso na medida em que os sujeitos se constroem discursivamente.

Se considerarmos que a complexidade da vida impõe ao ator social diferentes maneiras de experienciar a realidade, pode-se afirmar que ele participa de diferentes realidades 
por meio de representações. São as representações que lhe permitem acionar códigos para transitar no espaço social e produzir sentidos com base em universos simbólicos sobre si e sobre o outro no processo de construção social da realidade. Nesse sentido, as representações definem sua identidade social, pois sua subjetividade orienta seu agir no mundo. 0 ato de pensar está sujeito também aos limites dados pelas possibilidades estabelecidas nas condições socioculturais dadas pelo tempo e espaço. Se considerarmos que as representações são constituídas de valores associados a ordens morais locais, permeadas por uma afetividade, podemos pressupor que elas se constituem em conhecimentos práticos que nos permitem sermos inseridos no mundo social; em última instância, são as representações que conferem sentido às práticas sociais. Para Hall,

A linguagem e a representação produzem sentido, mas como o conhecimento elaborado por determinado discurso se relaciona com o poder, regula condutas, inventa e constrói identidades e subjetividades e define o modo pelo qual certos objetos são representados, concebidos, experimentados e analisados (Hall, 2016: 27).

Os discursos, ao articularem diferentes interesses calcados em estruturas institucionais, revelam, nas várias experiências pessoais e grupais, os conceitos, as afirmações e as explicações que configuram as representações sociais. Representações estas veiculadas nos discursos internos e externos aos sujeitos, que, nas suas subjetividades, a um só tempo interpretam e constroem as realidades às quais estão subsumidos em um tempo e espaço histórico. As representações sociais são mobilizadas ininterruptamente pelos sujeitos nos processos dialógicos quando eles estão em relação com o outro. Assim, pensar as identidades individuais é pensar o cotidiano com base nas interações sociais postas.

Ao se refletir a respeito das mulheres guerrilheiras, não se pode perder de vista 0 fato de a subjetividade dessas mulheres se construir alicerçada nas identificações culturais e nas representações socialmente forjadas no espaço social ao qual estavam subsumidas. Se quisermos compreender, do ponto de vista histórico, os mecanismos que engendram sua ação no espaço da política, faz-se mister considerarmos a luta armada como um espaço que colocou em contato grupos sociais, com expressões culturais que ampliaram as possibilidades de diferentes indivíduos e uma pauta comum de reivindicação, congregarem e compartilharem representações e identidades.

Para Pollack (1992: 204), a identidade pode ser entendida como a "imagem de si, para si e para os outros". A constituição da identidade, ao arregimentar a noção de pertencimento ao grupo, a percepção de continuidade do indivíduo no tempo e no espaço histórico e a noção de uma narrativa com pseudocoerência, permite a sensação de um indivíduo unificado. 
Todavia, não se pode esquecer que esses elementos estão vinculados à identidade social, já que a imagem de si se insere nas transformações relacionadas ao contexto sócio-histórico no qual vive o sujeito e o seu grupo. Isso fica claro na fala de Joana, hoje com 71 anos, que rememora sua história com uma narrativa na qual se identifica por sua filiação e, posteriormente, por meio dos grupos aos quais se filiou em sua trajetória de constituição identitária enquanto guerrilheira:

Então, eu me chamo Joana, nasci em 1950, janeiro de 50, vivi em poço de Goiás, porque meu pai era coletor, porque na época fiscal de renda chamava-se coletor e moramos muito tempo no interior de Goiás e nós fomos pra Goiânia, e em Goiânia que eu conheci um pouco do movimento que chamava. O movimento começou como estudante assim, tinha os estudantes participando do DCE naquela época, e de repente eu resolvi mesmo participar de verdade e ir pra... pro movimento de guerrilha. E esse movimento, várias pessoas que vocês conhecem hoje, Zé Dirceu, Genoíno, Dilma, tudo participou desse movimento, eu era da mesma tendência participei da VAR-Palmares que é o que é da... que a Dilma participou também (Joana, Informação Verbal).

Não obstante essas ideias de singularidade e unicidade tidas como imanentes ao que no senso comum se denomina de identidade uma vez que pressupõem certo caráter de continuidade e reconhecimento de si mesmo ao longo do tempo, não podemos deixar de admitir que a temporalidade identitária reproduz a tensão dialética entre o igual e o diferente, a continuidade e a descontinuidade, a unicidade e a multiplicidade. Isso se explicita na narrativa de Joana quando ela define sua identidade pelas vivências experienciadas nas múltiplas relações vividas por ela nos diferentes grupos sociais. A identidade por nós construída tem íntima relação com o grupo, é nos vínculos com o outro em um processo de alteridade que os indivíduos se definem. É na complexidade da estrutura social que categorias sociais como poder, gênero, classe, raça, entre tantas outras, que o indivíduo estabelece sua identidade em um processo de comparação social intragrupo e extragrupo.

Para Tajfel (1993), pertencer não é algo simples, pois envolve um processo de interação mútua e contínua. 0 sentimento de pertença grupal possui um caráter de volatilidade intensa, visto que ser membro de um grupo é compartilhar crenças, é agir, é estabelecer relações nas quais estão presentes processos de classificação e percepções sobre o estabelecimento de processos de diferenciação de si em relação ao próprio grupo e do grupo em relação a outros grupos. Não se pode esquecer que os indivíduos estão sempre inseridos em múltiplas e diferentes categorias sociais, portanto em vários grupos. É preciso considerar que os grupos não têm fronteiras precisas e estão em relação com os outros; por isso nos filiamos a diferentes grupos no estabelecimento do nosso sentimento de pertença. 
Um dia eu sentei na sala com papai e mamãe e fiz um discurso imenso sobre a importância da luta armada. Nós dizíamos para as nossas famílias que o socialismo era o ideal, que era a única realidade boa para o Brasil, e que a gente estava ali lutando para uma vida melhor, pela liberdade, pela democracia. Eu já estava tão envolvida com a luta armada que não havia argumento nenhum que me tiraria da organização...A minha mãe reagiu de forma contrária, ela disse que não aceitaria de jeito nenhum, mas eu fui firme e falei que ia embora de casa, que não ia sair da organização e que ia para a clandestinidade... Foi aí que ela disse que se não tivesse jeito que então ela ia aceitar, mas eu me lembro que meu pai aceitou mais tranquilamente, sabe [...] (Joana, Informação Verbal).

Assim, a identificação com o grupo possibilita laços de solidariedade. No caso de Joana, estabelecer esses laços nos seus grupos de guerrilha foi fundamental para as ações políticas de resistência, o que contribuiu, naquele contexto, para reafirmar o direito da mulher em se constituir como sujeito político e redefinir a categoria social do gênero como possibilitadora do exercício da cidadania.

Uma outra ação do SAV em que eu fui responsável foi o assalto da Casa do Sertanejo, lá tinha armas, por isso nós roubamos a loja... Eu vigiei durante meses... Eu usava uniforme de estudante para ninguém desconfiar, sempre a gente usava os uniformes, quem vigiava era mulher, ninguém desconfiava, para não levantar suspeita. Olha, na hora do roubo nós falávamos que a ação era para o bem do país. Era um discurso grande que a pessoa ficava olhando... Se soubéssemos que alguém tinha arma, nós roubávamos, inclusive da família. Eu mesmo roubei arma do meu avô, a Maria Helena também roubou, a gente roubava mesmo [...] (Joana, Informação Verbal).

Os processos de categorização social e de identificação, no que tange à ação da muIher e às relações de gênero no seio da luta armada, constroem um processo de inclusão da mulher na arena política nas disputas de memória sobre as narrativas postas a respeito da ditadura militar. Na fala de Joana é possível observar a presença de ações como prováveis "reguladores das relações políticas" (Souza, 2004: 64) no que se refere às mulheres. Nessas ações estão estabelecidos processos de categorização que implicam diferenciações no grupo pautadas por aquilo que só elas podiam fazer. Essas categorizações estão baseadas em relações de gênero, que permitiam identificar o masculino como diferente; logo, vigiar e não despertar suspeitas era coisa de mulher, já que era impensável uma ação política de resistência nesse espaço pensado a priori como masculino. Segundo Souza (2004), esse processo de instituição de categorias sociais específicas é historicamente construído. Ao se utilizarem os jogos de gênero na ação guerrilheira, as mulheres construíram estratégias e táticas nas quais fizeram uso do imaginário social instituído sobre o lugar da mulher para se apropriarem do espaço público como sujeitos políticos. 
Se a luta armada se configurou como uma possibilidade de se engajar em um projeto, pode-se afirmar que ela reorientou papéis de gênero e conferiu outros significados às práticas das mulheres no que se refere às suas trajetórias e identidades.

Então a gente tinha o Mauro Borges como governador, não foi eu que elegi porque eu tinha só 14 anos, mas meu pai, todo mundo, né... Foi eleito, aí chegou lá em Goiânia... Lembro os estudantes, as pessoas mais velhas, todo mundo ia pra praça, praça de Goiânia, pra não deixar... e o Mauro borges resistiu um pouco mas aí não teve jeito, teve toda uma tropa de polícia e... aviões e tudo mais, né? Não tem jeito, aí ele saiu, então me lembro depois da primeira vez do movimento assim. Então depois foi entrando em contato cada vez mais e me envolvendo cada vez mais, sabe? Com a política, que era uma política que a gente... naquela época nós achávamos que foi a juventude, acho que foi uma coisa que... não tinha outra coisa pra fazer a não ser isso... Olha, a primeira ação que eu fiz foi marcante, foi na época dos jogos... Eu e João fizemos a bomba e colocamos lá, mas ela não explodiu, e as impressões digitais dele ficaram na bomba, elas tavam lá, elas identificaram ele e ele foi para a clandestinidade... O nosso grupo era sério, era um bando de menino, de estudante, mas a gente acreditava mesmo na luta armada [...] (Joana, Informação Verbal).

Ao optar pelo projeto revolucionário da esquerda armada, Joana acreditava na possibilidade de derrotar o regime militar, crença esta que se desfez logo depois, com o aperfeiçoamento das estratégias de perseguição e aumento da violência. Essa juventude viu suas propostas serem estancadas pela Lei de Segurança Nacional, pois: "Hoje a gente vê, antes de tudo acabar, como todo mundo foi preso e tal e essa coisa toda, em 71 ainda. A gente já tinha, já sabia que não era a solução... pegar nas armas, que num dava" (Joana, Informação Verbal).

As suas narrativas expressam memórias em que o relembrado está em constante movimento. Isso é perceptível nas falas das duas, quando expressam a preocupação com a democracia mediante as crises políticas do momento em que elas deram seus testemunhos. Percebe-se que, em função das mudanças na esfera pública, conforme Thompson, as memórias que "escolhemos para recordar e relatar (e, portanto, relembrar) e como damos sentido a elas são coisas que mudam com o passar do tempo" (Thompson, 1997: 57).

Durante o regime militar e especialmente o processo de luta armada, aquelas que conseguiram se inserir nas organizações de resistência tiveram oportunidades de conhecer e estudar teorias políticas e econômicas. Adentraram o espaço dos debates e das contestações de forma que foram instrumentalizadas a contestarem a mistificação da ideia de moralidade no que se referia à participação da mulher na esfera pública. 
E o dia a dia era um dia a dia comum de todo mundo, fazer almoço, fazer jantar, né? Mas fora isso tinha as ações, os encontros, os estudos, né? A gente pegava livro e fazia reuniões pra discutir aqueles livros, né? A gente discutia o que fazer, como fazer, quem ia e quem não ia [...] (Fernanda, Informação Verbal).

0 fato de estudar e se informar contribuiu para a permanência de muitas mulheres nos movimentos políticos de luta armada em oposição ao governo militar, ainda que esses movimentos tenha arregimentado uma pequena parcela da população. A entrada dessas muIheres no universo da guerrilha possibilitou a abertura para projetos pessoais que não estavam colocados para as gerações anteriores de mulheres. Para as jovens guerrilheiras, os modelos de mulher e de vida constituídos no paradigma do casamento e da criação dos filhos foram pensados sob uma nova configuração. Fernanda demonstra isso em sua fala:

Tava lembrando o quanto minha mãe sofreu, sofreu tanto nessa época de participação política e quando eu fui pros Estados Unidos também porque a gente foi como mão de obra, então pensa bem, você põe sua filha pra estudar piano mais de 10 anos, põe no francês, põe no balé e depois ela se manda pra não fazer nada... Pra não fazer nada, não, mas pra fazer coisas que não estão de acordo com o que a sociedade visa, a gente vive num local pra ocupar um espaço que não é respeitado e aí você já pensou, né, na filha... É... Pra você ver essas coisas (Fernanda, Informação Verbal).

Não podemos deixar de frisar que as experiências objetivas e subjetivas da ação contra o regime variaram amplamente de 1964 a 1985. É essa multiplicidade de posicionamentos que demarca a trajetória e a identidade social das mulheres entrevistadas que se tornaram militantes em frente daquelas que não optaram por essa trajetória. Nesse sentido, não podemos também generalizar o "ser mulher militante" para analisar os papéis assumidos por elas na arena política. É preciso visitar os contextos ideológicos, interpessoais, públicos e privados, pois a identidade de "mulher" comporta múltiplos significados, nos quais se intercala uma variedade de projetos em formação.

Ao nos apropriarmos dessas experiências pelas falas de Joana e Fernanda, temos a impressão de pequenos preenchimentos por vestígios históricos de lacunas pelas quais é possível a redefinição de identidades e representações possibilitadas pela história oral. Por meio de suas vozes, as mulheres guerrilheiras colocam-se como sujeitos históricos e sociais na medida em que seus depoimentos rompem com os discursos hegemônicos de uma história pautada por um regime de verdade que recusou, por muitos anos, seu protagonismo no processo de resistência à ditadura.

Histórias e identidades que pairavam nos palimpsestos da historiografia e hoje se revelam por meio história oral fazem-se visíveis nas falas daquelas que rememoram um pas- 
sado que ainda não passou. Afinal, como diz Fernanda, a experiência como guerrilheira foi importante "porque valeu sonhar!". Joana complementa:

E isso foi o que a guerrilha deixou, porque esse movimento ele deixou em todo mundo que participou, você pode ver, ou ele foi ser escritor, ou ele foi ser não sei o quê... Mas foi ser... Foi participar de outro movimento, viu?! Sempre foi participar de alguma outra coisa... É que é um movimento assim... Depois meus filhos, eles também. Quer dizer... tem umas coisas assim que eu falo que não arrependo por isso, porque acho que foi bom porque abre a cabeça da gente sabe?... E sempre... sempre sabendo que política é a base, você tem que participar da política, né? (Joana, Informação Verbal).

Constituir uma história não fundamentalista do gênero é construir uma história que retém seu poder de explicação e seu interesse na mudança, sem reproduzir categorias naturalizadas. Cabe salientar que a análise do historiador deve pautar-se em categorias historicizadas na produção do conhecimento, no qual se pressupõe uma posição política ligada a um lugar de fala.

\section{CONSIDERAÇÕES FINAIS}

bordar as experiências das guerrilheiras no âmbito das relações de gênero configura-se
não como a origem de uma explicação que reifique a experiência de cada uma delas; ao contrário, a experiência como exercício político dessas relações é o que nos interessa. Nesse diálogo entre o historiador e o depoente, propiciado pela história oral, o objetivo é produzir fontes que nos possibilitem ler as experiências como algo que foi vivido pelo sujeito, mas também como algo que não permitiu que outras possíveis fossem vividas, ou que outras fossem vividas de uma perspectiva tanto individual como social e política.

Walter Benjamin revela-nos que a narrativa possui uma função utilitária: " [...] essa utilidade pode consistir seja num ensinamento moral, seja numa sugestão prática, seja num provérbio ou numa norma de vida" (Benjamin, 1996: 200). Para as nossas narradoras, 0 ato de lembrar e verbalizar essas lembranças é, também, ensinar e alertar a sociedade para uma história inconclusa das mulheres na ditadura militar. As suas experiências fundamentam não só o conhecimento, mas a análise que empreendemos na construção de conhecimentos sobre o período ditatorial no processo de resistência empreendido pelas guerrilheiras. Pensar a experiência da guerrilheira com base na relação entre história oral e história das mulheres é o que nos permite historicizar a construção das suas identidades e representações na dinâmica posta na trama histórica, como condutoras e partícipes de uma mudança política e social de compreensão do seu papel na sociedade. 
Conflitos de interesse: nada a declarar.

Fonte de financiamento: nenhuma.

\section{NOTA}

1 A entrevista com Joana ocorreu no dia 4 de fevereiro de 2016, em sua residência. Iniciou-se às $15 \mathrm{~h}$ e finalizou às $18 \mathrm{~h}$.

2 A entrevista com Fernanda ocorreu no dia 6 de fevereiro de 2016, em sua residência, com duração de 4 horas, iniciando-se às $14 \mathrm{~h}$ e finalizando às $18 \mathrm{~h}$.

\section{REFERÊNCIAS BIBLIOGRÁFICAS}

ABREU, A. A. Quando eles eram jovens revolucionários. In: VIANNA, H. (ed.). Galeras cariocas: territórios de conflitos e encontros culturais. Rio de Janeiro: Editora UFRJ, 1997. p. 181-205.

BENJAMIN, W. Sobre o conceito de história. In: BENJAMIN, W. Obras escolhidas: Magia e técnica, arte e política. São Paulo: Brasiliense, 1996. p. 222-234.

DAVIS, N. Z. "Women's History" in transition: the European Case. Feminist Studies, New York, v. 3, n. 3/4, p. 83-103, 1976. https://doi.org/10.2307/3177729.

FERREIRA, A. C.; GROSSI, Y. de S. A narrativa na trama da subjetividade: perspectivas e desafios. História Oral, Rio de Janeiro, v. 7, p. 41-59, 2004. https://doi.org/10.51880/ho.v7i0.75.

FUNCK, S. Desafios atuais dos feminismos. In: STEVENS, C.; OLIVEIRA, S. R.; ZANELLO, V. (orgs.). Estudos feministas e de gênero: articulações e perspectivas. Florianópolis: Editora Mulheres, 2014. p. 22-35.

HALL, S. Cultura e representação. Rio de Janeiro: Editora PUC-Rio, Apicuri, 2016.

POLLAK, M. Memória, esquecimento, silêncio. Estudos Históricos, Rio de Janeiro, v. 2, n. 3, p. 3-15, 1989.

POLLAK, M. Memória e identidade social. Estudos Históricos, Rio de Janeiro, v. 5, n. 10, p. 200-215, 1992.

PORTELLI, A. Tentando aprender um pouquinho: algumas reflexões sobre a ética na história oral. Projeto História, São Paulo, n. 15, p. 13-49, 1997.

RICOEUR, P. A memória, a história, o esquecimento. São Paulo: Editora da Unicamp, 2007.

RIDENTI, M. S. As mulheres na política brasileira: os tempos de chumbo. Tempo Social, São Paulo, v. 2, n. 2, p. 113-128, 1990. https://doi.org/10.1590/ts.v2i2.84806.

ROVAl, M. G. O. 0 direito à memória: a história oral de mulheres que lutaram contra a ditadura militar (1964-84). Revista Tempo e Argumento, Florianópolis, v. 5, n. 10, p. 108-132, 2013. https://doi.org/10.59 65/2175180305102013108.

SALVATICI, S. Memórias de gênero: reflexões sabre a história oral de mulheres. Trad. Luiz Antonio Rodrigues Ribeiro Campos. História Oral, Rio de Janeiro, v. 8, n. 1, p. 29-42, 2005. https://doi.org/10.51880/ho.v8i1.114. 
SARLO, B. Tempo passado: cultura da memória e guinada subjetiva. São Paulo, 2007.

SARTI, C. A. O feminismo brasileiro desde os anos de 1970: revisitando uma trajetória. Estudos Feministas, Florianópolis, v. 1, n. 22, p. 35-50, 2004. https://doi.org/10.1590/S0104-026X2004000200003.

SCOTT, J. W. A invisibilidade da experiência. Projeto História, São Paulo, n. 16, p. 297-325, 1998.

SOUZA, L. Processos de categorização e identidade: solidariedade, exclusão e violência. In: TRINDADE, Z. A.; SOUZA, L. (eds.). Violência e exclusão: convivendo com paradoxos. São Paulo: Casa do Psicólogo, 2004. p. 57-74.

TAJFEL, H. Grupos humanos e categorias sociais. Lisboa: Livros Horizonte, 1993. v. II.

THOMPSON, A. Recompondo a memória: questões sobre a relação entre a história oral e as memórias. Projeto História, São Paulo, v. 15, p. 51-84, 1997. 